\title{
Corporate Governance, Cost of Capital and Value Creation: Evidence from Indian Firms
}

\author{
Akarsh Singhal \\ Shaheed Sukhdev College of Business Studies, University of Delhi
}

\begin{abstract}
In this paper, we investigate the impact of corporate governance on firm performance and valuation in India. Our study is the first to use a composite measure of corporate governance to examine the impact of corporate governance on Indian firms' performance and valuation. Because agency theory suggests that companies with better corporate governance standards perform better, we propose that better governed Indian firms should have greater performance lower cost of capital and thus, higher valuation.
\end{abstract}

To achieve this objective, we use WaCC, Cost of Equity, Cost of Debt, Tobin Q, Return on Capital Employed, Return on equity, Sales growth, as the key variables that defined the cost of capital and performance of the firm respectively. On the other hand, for the measure of corporate governance, we use Board Independence, Board size, CEO Duality and ownership pattern in the company.

Most importantly, we find that our composite measure of corporate governance is positively and significantly associated with firm performance and valuation. In addition, our results show that ownership concentration and board independence have a positive impact on firm performance and valuation.

We use a sample of large firms over 10 years in a unique governance setting, India, to analyze the role that the variation in firm-level corporate governance mechanisms play in explaining a firm's cost of capital. We find that greater insider ownership, the presence of institutional blockholders and independent boards all serve to reduce the perceived risk of a firm, thereby leading investors to demand lower rates of return on capital provided. This highlights the important role that corporate governance plays in creating value for shareholders by reducing the cost of external financing. Given the inconclusiveness of existing literature that uses $Q$ to measure firm value, this research suggests an alternative and potentially more suitable way to investigate the impact of corporate governance on firm value.

Finally we design a predictive model using discriminant analysis, which we name as "Singhal's V-score Model", that can help a potential investor predict whether a firm will dampen or add higher value (spread) to his shareholdings, given the state of governance mechanisms that the management of firm employs. The $V$-score greater than 1.168 suggests that the firm will diminish the value of investor's investment and a $V$-score less than -0.888 suggests that the firm will add higher value to the investments either by earning superior returns \& performance or bearing lower cost of funds invested.

These findings have implications for policy makers, researchers, managers, and investors in general and those in emerging markets in particular.

Key Words: Corporate Governance; Agency Cost, Firm Valuation; Ownership; Tobin's Q; Weighted Average Cost of Capital, Spread, Emerging markets (India)

Field of Research: Finance

\section{Introduction}

The role of corporate governance in creating value for shareholders has become the subject of intense interest in corporate finance research, especially after the plethora of corporate scams and debacles in recent times.

Corporate governance issues flow from the concept of accountability and governance and assume greater significance and magnitude in the corporate form of organisation where the ownership and management of organisation are distanced.

Some researchers empirically find that good corporate governance positively affects firm performance and market value (e.g., Gompers et al. 2003; Brown and Caylor 2006a; 2006b; Dittmar and Mahrt-Smith 2007). 
Most of these studies focus on corporate governance in developed markets, especially the US equity markets. For example, Gompers et al. (2003) find that better-governed US firms during the 1990s have higher operating performance and higher value in stock markets, suggesting investors in the United States factor in corporate governance when making their investment decisions. However, the importance of corporate governance in emerging markets, such as the equity markets in India, remains under-explored.

In this study, we examine the value-creating role of corporate governance mechanisms using an alternative approach to those used in most previous studies. Rather than measuring firm value directly using variables such as Tobin's Q or EBIT, we investigate the relation between a firm's governance mechanisms and its cost of capital. While most previous studies focus on the fact that a strong governance environment can limit divergence of cash flows or earnings, and thus increase a firm's valuation, we argue that it can also reduce a firm's cost of capital $\mathrm{K}_{\mathrm{o}}$ (and hence, implicitly increase firm Value).

$$
\text { Value of Firm }=\frac{\text { Earnings [EBIT ] }}{\text { Cost of Capital [Ko] }}
$$

A firm's Cost of Capital (K) reflects investors' required return based on the firm's systematic risk. Various studies suggest that firm's with weak governance perform particularly poorly during market downturns and thus should be subject to a higher cost of capital. For example, when external monitoring of insiders is inadequate, managers may undertake excessive borrowings to finance empire building expansions which increase a firm's exposure to market-wide risk and ultimately increase the cost of capital. In addition, the cost of capital for poorly governed firms can also increase because a lack of corporate transparency leads to higher issuing and transaction costs.

The use of the cost of capital to measure value has additional advantages over Tobin's Q, which is widely used as a performance measure in the corporate finance literature. For instance, the measurement of $Q$ is subject to accounting treatment of balance sheet items. Further, changes in Tobin's Q can also reflect a firm's future growth opportunities which arise in part from factors exogenous to the governance of the firm, such as economic and industry conditions.

The cost of capital on the other hand reflects the required rate of return to capital, which is based on the current risk of the firm's operations and thus is able to react more accurately to year to year changes to a firm's governance environments without being influenced by exogenous factors that affect future growth and profitability.

The Indian corporate system has a relatively unique environment with respect to corporate governance mechanisms. The Indian corporates are governed by the Company's Act of 1956 that follows more or less the UK model. The pattern of private companies is mostly that of closely held or dominated by a founder, his family and associates. Available literature on corporate governance and the way companies are structured and run indicate that India shares many features of the German Japanese model, but of late, recommendations of various committees and consequent legislative measures are driving the country to adopt increasingly the AngloAmerican model. In addition, the Indian market is not a bank-centered market, in which banks take an active role as an equity holder and corporate monitor, as in Germany and Japan. This makes the role of internal governance mechanisms such as independent boards, and management incentives potentially more important in India.

To analyze the relationship between a firm's cost of capital and its governance, we examine a long time series of governance and cost of capital data on Indian firms (10 years).

We find that stronger firm-level governance characteristics, such as board size, board independence, the presence of institutional blockholders and higher insider ownership all significantly help in either reducing a firm's cost of capital or enhancing its performance and thus implicitly enhance firm value.

Our focus on the cost of capital highlights that strong corporate governance can reduce a firm's systematic risk and information asymmetry, in addition to the role of limiting cash flows divergence. This suggests that that corporate governance can influence a firm's value indirectly through its cost of capital. 


\section{Objectives}

The objectives of the study are as follows:

- To identify the relationship between corporate governance variables and firm level corporate performance and analyze the reasons behind the results.

- To identify the relationship between corporate governance variables and cost of capital of firm and analyze the reasons behind the results.

- To compare \& contrast the results shown by corporate performance variables and cost of capital variables (above) and identify which of the two is a better capable in explaining the value improvement/degradation in a firm.

- To identify the relationship between corporate governance variables and Spread of the firm (RoCE $\mathrm{K}_{\mathrm{o}}$ ) and analyze the reasons behind the results.

- Integrating the results derived above to design a High-Value Addition predictive model in form of Singhal's V-score model.

\section{Literature Review}

Numerous prior international and Indian studies have examined the relation between firm performance and governance mechanisms; like Agrawal and Knober (1996), Demsetz and Villalonga (2001), Himmelberg et al. (1999), Gompers et al. (2003). These measures include board size, board composition, and independence, $\mathrm{CEO}$ and chairperson duality, and executive remuneration and compensation structure.

Generally, empirical research has remained indecisive regarding the extent to which individual monitoring mechanisms enhance firm performance and shareholder value. The prior literature has tended to examine performance by focusing on accounting returns like RoE and changes in firm value using Tobin's Q. Alternative performance measures used more recently include the individual costs of equity or debt.

Corporate governance can reduce the non-diversifiable risk of expropriation by corporate insiders. The degree of expropriation by corporate insiders depends on the investment opportunity and the cost of expropriation, among other factors. A firm's investment opportunities and thus expropriation by insiders, have a non-diversifiable component that depends on macroeconomic conditions. Thus a negative relation between expropriation and market conditions is suggested. This relationship can magnify the systematic risk of a firm, which must be compensated by a higher required rate of return. Better corporate governance imposes higher costs on expropriation, thus reducing the negative relation between the degree of expropriation and market conditions.

Further, better corporate governance lowers the cost of equity by reducing the cost of external monitoring by outside investors. Investors incur external monitoring costs to ensure a given payoff from a firm's management. Monitoring costs are compensated by a higher required rate of return. Thus, corporate governance reduces the cost of equity by limiting opportunistic insider trading.

Previous empirical research has examined whether other corporate governance mechanisms, apart from disclosure, have an impact on a company's cost of equity. Disclosure and non-disclosure governance mechanisms such as board independence and minority shareholder protection have been found to have a significant negative impact on a firm's cost of equity capital in nine emerging Asian economies. [Ashbaugh et al. (2005), Bhoraj and Sengupta (2003), Anderson et al (2004) and Klock et al (2005).]

The existing literature that presents the link between performance and mechanisms to control agency problems assumes that governance affects firm valuation by increasing expected cash flow, since less cash flow is diverted away from shareholders. The idea that governance can enhance firm value through reducing the cost of capital, however, is not explicitly examined in these studies. The prior empirical evidence that has examined the cost of equity suggests that governance mechanisms do enhance firm value in this manner. The full extent of this relationship however, can be more accurately tested by considering a firm's overall cost of capital i.e. $\mathrm{WaCC}$ (the cost of both its debt and equity). 
$\underline{\text { Data }}$

\section{Research Design}

\section{Sample Selection}

The guidelines on corporate governance issued by SEBI (1999) made it mandatory for all the listed companies to adopt them in a phased manner. The BSE 100, NSE 50 companies and the Category A companies had to adhere to the guidelines by March 31,2001. This classification virtually covers all BSE 30 companies of SENSEX.

So, our data set initially comprises of the SENSEX 30 companies of Bombay Stock Exchange (BSE). In all, data for 10 financial years, from FY 2003-2004 to FY 2012-2013 were included in the analysis. The data sources were the Annual Reports of the companies, database like Capitaline \& TradingEconomics.com, and the reports filed by BSE as a part of the listing requirements.

From the 30 companies selected above, those companies which were not listed for all the ten years under consideration were excluded. We also delete firms for which we cannot obtain a full set of variables described below. Our final sample comprises 22Companies and our period of investigation spans from 2004 to 2013.The ten-year window allows for considerable variation in firm-level governance factors, which is important given the typically slow changes in these factors through time. The total number of firm-year observations is 4840 .

\section{Variable Formation}

To study the relationship between the firm-level corporate governance, firm-level corporate performance \& corporate cost of funds, the following variables were used, which were endogenous or exogenous, depending upon the hypothesis being tested:

\section{Firm-Level Corporate Governance:}

For each firm, we collect information on three key governance mechanisms, (i) board independence and size, (ii) the extent of insider shareholdings and (iii) the extent of outsider shareholdings.

i. Board Independence (BoardInd): The number of independent non-executive directors over total number of directors in a company is used as a proxy for board independence which is a measure of good corporate governance. We classify directors as non-independent if they were current or exemployees, had business dealings with the firm, or were related (by family) to executive directors.

The board of directors' role is to provide independent oversight of management and hold management accountable to shareholders for its actions. The duty of the board of directors can be undermined if directors become allied with managers rather than protecting the interests of shareholders. In this sense, the lack of board independence from management is a governance risk that can materialize into reduced shareholder's wealth.

Therefore, our examination of the effect of board structure on the cost of capital provides an additional avenue to gain some insight into this issue.

ii. Board Size (BoardSize): Limiting board size is believed to improve firm performance. Although there is no scientific limit as to the size of the board, or any level identified as optimal for the size of the board, empirical research has established that the size of the board has a significant influence on the performance of firms. This is documented in the work of Anderson et al (2004) which shows that cost of debt is lower for larger boards. There are other benefits established for larger boards especially in the works of Lipton and Lorsch (1992); and Jensen (1993). We measure board size as the natural logarithm of the total number of directors on the board (LBoardSize).

Previous studies examining the link between board structure and firm performance are inconclusive. Jensen (1993) finds out that directors in a large board have diverse opinions and consensus is difficult to reach, then the efficiency becomes lower, and the situation could deteriorate if directors increase (Lipton and Lorsch, 1992). Nevertheless, Bacon (1973) holds an opposite opinion that larger board implies members with diverse 
background and viewpoints, which is helpful for the quality of decisions; additionally, a wide range of their interests may neutralize decisions.

iii. CEO/MD Duality (ExecDuality): As the chairman serves as the executive, playing roles of decisionmaker and supervisor simultaneously, the board could lose its independence and monitoring power, consequencely performing a weak function as a bulwark against agency problems. Daliy and Dalton (1993), Dahya et al. (1996) attest to that CEO duality seems to deteriorate firm performance.

iv. InsiderHold: It is the proportion of a firm's stock that is held by corporate insiders. The impact of insider ownership on firm value can be non-monotonous. On the one hand, when managerial compensation is sensitive to firm performance, managers are more likely to pursue value maximizing strategies (the incentive effect). On the other hand, excessive insider ownership may insulate managers from outside shareholder monitoring, and managers may also begin to pursue risk reduction strategies to protect their large undiversified shareholding. Thus, very large controlling shareholdings by insiders can adversely affect firm value (the entrenchment effect). We use the square of insider ownership (SqInsiderHold) to control for the nonlinear (inverted U-shape) relationship between value and managerial ownership.

v. Institutional Block Shareholding: The second ownership variable is the percentage ownership belonging to institutional block shareholders (InsttBlockHold), where a block holding is defined as a holding which is equal to or more than $5 \%$ of total ownership. Block shareholders are important for effective corporate governance since they can exercise their voting power to curtail value destroying behaviour by management. The relatively large size of their shareholdings also provides a greater incentive to monitor than those of dispersed minority shareholders. Institutional block shareholders such as banks, superannuation (pension) funds and mutual funds are a unique class of blockholders since they are likely to be independent of management and have the ability to induce pressure on management to protect their minority interest.

vi. Non-Institutional Block Shareholding: These are the other block shareholders that are not financial institutions. These shareholders are generally the parent and associate companies. We measure their total percentage ownership and label this variable (NonInsttBlockHold). The effect of this variable on company value and performance is ambiguous since these block shareholders are also capable of colluding with each other and with insiders to expropriate minorities.

\section{Firm-Level Characteristics (Control Variables):}

The regression results between firm performance/cost of capital and corporate governance variables were subject to control for a number of factors that could affect firm performance, cost of capital, corporate governance variables or all of the three. These control variables are:

i. $\quad$ Firm Size (FirmSize): It is measured by Log of Sales. Log transformation of this variable is used to correct for the high degree of skewness in the firm size, thus ensuring that the data is properly distributed.

ii. Leverage: As measured by (Long-term debt/Equity) to control for variations in capital structure and as a proxy for default financial risk.

iii. Risk: It refers to the systematic risk of industry to which the firm belongs and is measured by Beta (1year).

iv. Age: It is measured as the number of years for which the company has been in existence since incorporation. To correct for high degree of skewness, we take Log of Age (LogAge).

v. Diversification: It is measured as the number of business segments (SBUs) for which the company reports. As per Yermack (1996), "the diversified firms are valued less highly in the capital markets than the standalone businesses. The diversified companies are likely to have larger boards, because many boards grow in size when companies make acquisitions and because boards of conglomerates can seek outside expertise for a greater number of industries." 
vi. Type of Company (CoType...): whether govt.-owned, Indian private sector or foreign owned MNC, the same if reflected by using dummy variables for different categories.

vii. Industry Control (Sect...): This is for manufacturing or services or financial services firms and we use dummy variables for different categories.

viii. Credit Rating received for Long term debt instruments (CreditRating): When the companies issue debentures or similar long term debt securities in the market, they get credit ratings for the same from different credit rating agencies, which further affects their cost of raising funds from the market. We classify credit ratings into two classes - "High Credit Rating" (such as AAA, AA) and "Moderate/Low Credit Rating" (such as A, BBB, BB). We use dummy variables to reflect the two categories.

\section{Firm-Level Cost of Capital:}

As a part of our study, we employ Cost of Capital as the dependent variable against Firm-Level Corporate Governance factors (subject to control variables also) as independent variables. We anticipate a low degree of resultant variance in Cost of Capital factors, so that they can emerge out to be more stable $\&$ better measure to judge Value of firm vis-à-vis corporate governance factors.

i. Cost of Equity $\left(\mathbf{K}_{\mathrm{e}}\right)$ :This is calculated using CAPM. The risk free rate $\left(\mathrm{R}_{\mathrm{f}}\right)$ is calculated using the average yield on 10 year Indian Government Bonds. One yearly Beta values are taken for every company from Capitaline database. Market Return $\left(\mathrm{R}_{\mathrm{m}}\right)$ is calculated as one yearly return of SENSEX.

$$
\text { Expected } \mathrm{R}_{\mathrm{i}}\left(\text { or } \mathrm{K}_{\mathrm{e}}\right)=\mathrm{R}_{\mathrm{f}}+\beta\left(\mathrm{R}_{\mathrm{m}}-\mathrm{R}_{\mathrm{f}}\right)
$$

ii. Cost of Debt $\left(\mathbf{K}_{\mathbf{d}}\right)$ : This is calculated by taking post-corporate tax Interest liability of firms over their outstanding Total Debt (taken at book value).

$$
\mathrm{K}_{\mathrm{d}}=\frac{\text { Interest }(1-\mathrm{t})}{\text { Total Debt }}
$$

iii. Weighted Average Cost of Capital (WaCC or $\mathbf{K}_{\mathbf{0}}$ ): This is calculated using weights of Market value of Equity (Market Capitalization) for $\mathrm{K}_{\mathrm{e}}$ and book value of Debt for $\mathrm{K}_{\mathrm{d}}$.

$$
\text { WaCC or } \mathrm{K}_{\mathrm{o}}=\frac{(\text { Market Value of Equity } \mathrm{x} \mathrm{Ke})+(\text { Book Value of Debt } \mathrm{x} \mathrm{Kd})}{\text { Market Value of Equity }+ \text { Book Value of Debt }}
$$

\section{Firm-Level Corporate Performance:}

Data on five measure of firm performance - each with support in the finance $\&$ accounting literature as a respectable measure of firm performance were collected, since there is no single ideal measure of long term firm performance. These measures are:

i. Tobin's Q: Computed as [MV of Equity + MV of Debt] / Total Assets, with the values computed at the year end. We use a slight modified version by replacing MV of Debt with BV of Debt. the modification was being done to make it compatible with the manner of reporting in the Indian context. Tobin $\mathrm{Q}$ is an unambiguous measure of value added by the management and can also capture the value of future investment opportunities.

$$
\text { Tobin } \mathrm{Q}=\frac{\text { (Market Value of Equity + Book Value of Debt })}{\text { Total Assets }}
$$

ii. Market-adjusted Stock Price returns (MASR): Computed by cumulating over the measurement period yearly stock returns minus returns on market index (SENSEX) without adjustment for beta. 


$$
\operatorname{MASR}=\mathrm{R}_{\mathrm{i}}-\mathrm{R}_{\mathrm{m}}
$$

iii. Revenue Growth: Computed as the arithmetic return of Net Sales of the company. It measures the multiple by which the firm size has been growing on year to year basis.

iv. RoCE: Return on capital employed measures the profitability and earnings generating aspect of the firm's investment of capital (be it through equity capital or debt capital or retained earnings). Computed as EBIT / Total Capital Invested in business.

v. RoE: Return on Equity measures the earnings available for equity shareholders after all fixed liabilities of the firm have been met. Computed as [EAT-Preference Dividend] / Equity capital.

\title{
Methodology
}

We employ a Panel Data model as it allows the researcher to capture both, the time-series and the cross-sectional relations (as per Green in 1997).

According the hypotheses proposed (mentioned in the next section), this study constructs a Regression model for carrying out empirical analysis, using SPSS.

\section{Model-1 : The relation between Corporate Governance and Firm Performance variables}

Firm Performance $=\alpha 0+\alpha 1$ Boardnd $+\alpha 2$ LBoardSize $+\alpha 3$ ExecDuality $+\alpha 4$ InsiderHold $+\alpha 5$ SqInsiderHold $+\alpha 6$ InsttBlockHold $+\alpha 7$ NonInsttBlockHold $+\gamma 1$ FirmSize $+\gamma 2$ Leverage $+\gamma 3$ Risk $+\gamma 4$ Diversification $+\gamma 5$ CoTypeIndPvt $+\gamma 6$ CoTypeMNC $+\gamma 7$ CoTypeGovt $+\gamma 8$ SectMft $+\gamma 9$ SectSevices $+\gamma 10$ SectFinServ $+\gamma 11$ CreditRating

\section{Model-2 : The relation between Corporate Governance and Cost of Capital variables}

Cost of Capital $=\beta o+\beta 1$ Boardnd $+\beta 2$ LBoardSize $+\beta 3$ ExecDuality $+\beta 4$ InsiderHold $+\beta 5$ SqInsiderHold $+\beta 6$ InsttBlockHold $+\beta 7$ NonInsttBlockHold $+\delta 1$ FirmSize $+\delta 2$ Leverage $+\delta 3$ Risk $+\delta 4$ Diversification $+\delta 5$ CoTypeIndPvt $+\delta 6$ CoTypeMNC $+\delta 7$ CoTypeGovt $+\delta 8$ SectMft $+\delta 9$ SectSevices $+\delta 10$ SectFinServ $+\delta 11$ CreditRating

\author{
Hypothesis \\ H1 : Board Independence is negatively related to Firm Performance. \\ $\mathrm{H} 2$ : Board Size is negatively related to Firm Performance. \\ H3 : Executive Duality is negatively related to Firm Performance. \\ H4 : Insider Shareholding is negatively related to Firm Performance. \\ H5 : Institutional Block Shareholding is negatively related to Firm Performance. \\ H6 : Non-Institutional Block Shareholding is negatively related to Firm Performance. \\ $\mathrm{H} 7$ : Board Independence is negatively related to Cost of Capital. \\ H8 : Board Size is negatively related to Cost of Capital. \\ H9 : Executive Duality is negatively related to Cost of Capital. \\ $\mathrm{H} 10$ : Insider Shareholding is negatively related to Cost of Capital. \\ H1 : Institutional Block Shareholding is negatively related to Cost of Capital. \\ H12 : Non-Institutional Block Shareholding is negatively related to Cost of Capital.
}

\section{Results And Findings}

\section{Descriptive Estimates}

The descriptive statistics presented the output of the mean, maximum, minimum and standard deviation for the data, the result is presented in TABLE-1 below. 


\begin{tabular}{|c|c|c|c|c|c|}
\hline \multicolumn{6}{|c|}{ Table-1 : Descriptive Statistics } \\
\hline & $\mathrm{N}$ & Minimum & Maximum & Mean & Std. Deviation \\
\hline Board Independence & 220 & .111111 & .857143 & .53675455 & .120841380 \\
\hline Board Size & 220 & 4 & 24 & 12.75 & 3.208 \\
\hline $\begin{array}{l}\text { \%age Shareholding by Promoters \& } \\
\text { Insiders }(\%)\end{array}$ & 220 & .000000 & $8.950000 \mathrm{E} 1$ & $4.33721818 \mathrm{E} 1$ & $2.708387252 \mathrm{E} 1$ \\
\hline $\begin{array}{l}\text { More than 5\% Shareholding by Financial } \\
\text { Instt (\%) }\end{array}$ & 220 & .0000 & 82.9100 & $3.115418 \mathrm{E} 1$ & 17.7767112 \\
\hline $\begin{array}{l}\text { More than 5\% Shareholding by Other } \\
\text { Ext. Instt (\%) }\end{array}$ & 220 & .0000 & 55.6400 & $8.736773 \mathrm{E} 0$ & 14.2633317 \\
\hline Cost of Equity (\%) & 220 & -67.59 & 125.44 & 19.9721 & 33.93567 \\
\hline Cost of Debt (\%) & 220 & -7.44085 & $3.68458 \mathrm{E} 2$ & $1.0282149 \mathrm{E} 1$ & 29.57764069 \\
\hline Overall Cost of Capital (\%) & 220 & -60.72 & 84.69 & 19.0555 & 28.33127 \\
\hline Tobin Q & 220 & .2004 & 152.7965 & $6.147305 \mathrm{E} 0$ & 11.5185717 \\
\hline Market Adjusted Stock Return (\%) & 220 & -117.49 & 186.49 & 4.6768 & 46.23720 \\
\hline Return on Capital Employed (\%) & 220 & .16 & 120.74 & 28.7215 & 21.16821 \\
\hline Return on Equity (\%) & 220 & -.27 & 114.14 & 27.3520 & 18.27488 \\
\hline 1 Year Beta & 220 & .2431 & 1.8512 & .909190 & .3243028 \\
\hline Debt/Equity & 220 & .00 & 18.44 & 1.3133 & 3.09467 \\
\hline Revenue Growth Rate (\%) & 220 & -39.43 & 97.21 & 19.1364 & 16.58368 \\
\hline Spread (\%) & 220 & $-7.40885 \mathrm{E} 1$ & $1.22562 \mathrm{E} 2$ & $9.6659269 \mathrm{E} 0$ & 34.70986297 \\
\hline Valid N (listwise) & 220 & & & & \\
\hline
\end{tabular}

The table shows the relationship in the data used for the analysis. The report shows clearly that the items used for the dependent and independent variables can be related as they are independent.

The data in TABLE-1 on the corporate governance variables shows that the mean board size of the companies studied has the maximum board size of about 24 while the minimum is about 4 . This suggests that, on the average, the companies considered have moderate board sizes. This is good in respect of the performance of these companies because it supports recent thinking about board sizes.

On board composition, the study shows that on an average, $54 \%$ of all board members are independent non-executive, which suggests that these boards are relatively independent. This goes in tandem with the compliance of SEBI Clause- 49 .

Simultaneously, these firms, on an average have 3\% shareholding by Banks, MFs, FIIs \& other financial institutes and about $8-9 \%$ block shareholding by other institutes \& trusts.

The SENSEX firms used for the study on the average have been performing with an annual average return of $29 \%$. The maximum on this performance variable is $121 \%$ with a minimum of $0.16 \%$. The revenue growth rate indicates that on average the companies have done good with $19 \%, 97 \%$ as the maximum while the minimum is about $-39 \%$.

Further look at the stock price return (market adjusted), the result indicates that there is a $5 \%$ return on average, with $186 \%$ been the maximum and $-117 \%$ minimum.

The SENSEX companies have an average leverage of 1.3 times, with some companies being totally unlevered (I.T. companies) and some being heavily levered upto 18 times. Following the same, BSE-30 companies, on an average, bear $20 \%$ cost of equity \& $1.03 \%$ cost of debt.

It is important to note that by using the cost of capital to infer performance, we intended to use a dependent variable that may have significantly less variation than $\mathrm{Q}$. But the descriptive stats reveal that for the present set of data, the Cost of Capital $\left(\mathrm{K}_{\mathrm{e}}, \mathrm{K}_{\mathrm{d}}\right.$ and $\left.\mathrm{K}_{\mathrm{o}}\right)$ have very high standard deviation vis-à-vis Tobin $\mathrm{Q}$, RoCE, RoE and Revenue Growth. quite healthy.

Furthermore, the companies on an average are able to add value to their firm by $9.66 \%$ spread, which is

\section{Regression Estimates with Corporate Performance}

In order to provide insight into the significance of our approach vis-à-vis past results, we first examine the effect of governance mechanisms on firm value proxied by Tobin $Q$ and firm performance measured by RoCE, RoE, Revenue Growth, MASR. 
TABLE-2 reports the estimation results for the cost of capital measure regressed on combinations of the governance variables.

\begin{tabular}{|c|c|c|c|c|c|c|}
\hline Dependent Veriebise $\rightarrow$ & $\begin{array}{l}\text { Expected } \\
\text { alon }\end{array}$ & $\begin{array}{l}\text { Tobin Q } \\
\text { u-sta-d } \\
\text { Cos" } E\end{array}$ & $\begin{array}{l}\text { RoCE } \\
\text { Uesta-d. } \\
\text { Cosel E) }\end{array}$ & $\begin{array}{c}\text { RoE } \\
\text { Unsta-d } \\
\text { Cose E) }\end{array}$ & $\begin{array}{l}\text { MAaR } \\
\text { U-sta-d } \\
\text { Cosw }(\text { ) }\end{array}$ & $\begin{array}{l}\text { Rev Growth } \\
\text { Unste-d } \\
\text { Cose E) }\end{array}$ \\
\hline (Conctent) & 2 & $\$ 4825$ & \begin{tabular}{l|l}
17570 \\
\end{tabular} & $\begin{array}{l}25: 999 \\
\end{array}$ & 47.781 & $\begin{array}{l}-16: 316 \\
\end{array}$ \\
\hline Eoerd Indspendanes (\%) & - & 10798 & 1998 & -1.984 & $\$ 4.44$ & 14880 \\
\hline Log of Boerd alze & - & -24802 & 10930 & -1.229 & 61.227 & -4.430 \\
\hline CEOO or MD Duelity & - & -8.497 & $-13: 23$ & -8.739 & 8900 & 5.189 \\
\hline $\begin{array}{l}\text { \%epe anereholding by } \\
\text { Promoterc \& incliderc (\%) }\end{array}$ & - & -088 & 341 & -159 & .184 & 169 \\
\hline $\begin{array}{l}\text { Aquere of incidar ritoiding } \\
\text { (\%) }\end{array}$ & - & 285 & -297 & -050 & -047 & -140 \\
\hline $\begin{array}{l}\text { Nore then } 5 \% \\
\text { ahereholding by Finenolel } \\
\text { Inett (\%) }\end{array}$ & - & 125 & -181 & -028 & 375 & $3: 6$ \\
\hline $\begin{array}{l}\text { Nore then } 696 \\
\text { anereholding by Other } \\
\text { Ext inett (96) }\end{array}$ & $?$ & 122 & -048 & .042 & 308 & -119 \\
\hline Log of asise & - & -12.740 & 2809 & 3697 & $-26 \$ 47$ & $\$ .190$ \\
\hline Debt Equity & ? & 302 & $-1 \leq 58$ & .195 & 1903 & 2114 \\
\hline 1 Year Bats & ? & $3: 26$ & -5.704 & $4: 386$ & -4847 & 2.395 \\
\hline $\log A \theta=$ & - & -476 & 2.133 & $8 s 8$ & 2.165 & -2885 \\
\hline No of ague & - & $\cdot \$ 98$ & 2349 & 725 & $-2 \mathrm{aas}$ & $-1,200$ \\
\hline Mejorly Foralon owned & 2 & 22975 & 46815 & $\$ 1.240$ & 10.107 & 216 \\
\hline $\begin{array}{l}\text { Mejorly lindien Gopt } \\
\text { owned }\end{array}$ & $?$ & $12: 88$ & $\leq: 881$ & -002 & 4383 & 387 \\
\hline $\begin{array}{l}\text { Menuseoturing \& Inductry } \\
\text { asotor }\end{array}$ & $?$ & $\$ 813$ & -7.853 & -5.696 & 13231 & 5.486 \\
\hline $\begin{array}{l}\text { Barvioe asotor exoluding } \\
\text { Finengiel Barvibac }\end{array}$ & $?$ & 17.120 & 3934 & $3: 58$ & $22: 50$ & 11.270 \\
\hline Finenolel aervisec sector & 2 & -521 & $-1 \leqq 48$ & -1.508 & $9: a 60$ & -8.705 \\
\hline Credit Reting & - & 8.412 & -5301 & 4.439 & $4: 21$ & $-4: 8: 0$ \\
\hline $\mathrm{R}^{i}$ & & 583 & $\$ 19$ & $\$ 41$ & 136 & 161 \\
\hline
\end{tabular}

\section{Board Independence \& Firm Performance:}

BoardInd is positively related to Tobin $\mathrm{Q}$ and is insensitive to the method of estimation as reflected by the significant positive coefficients across all estimations. BoardInd's relation with RoCE is similar, implying that greater proportion of independent directors on board can add value to the firm \& to its earnings. The result is consistent with the findings of other studies such as Weisbach 1988, and Brickleyet al.1994. In their study they are of the opinion that where there are more outside directors they will support the beneficial monitoring and advisory functions thereby strengthening the monitoring of the shareholders fund.

However, BoardInd is negatively related to MASR and RoE. This result is consistent with the findings of Agrawal\&Knoeber (1996). In their study they found that boards expanded for other reasons often result in too many outsiders on the board, which does not help performance.

Thus, our H1 stands partially rejected.

\section{Board Size\& Firm Performance:}

Board Size is negatively related to Tobin Q, Revenue Growth and RoE, implying that larger the number of members on board, more possibility of collusion among them thereby hampering the firm performance. However, RoCE\& MASR is positively aligned to Board Size (taken as Log).

Thus, our $\mathrm{H} 2$ stands partially accepted.

\section{Executive Duality \& Firm Performance:}

$\mathrm{CEO} / \mathrm{MD}$ Duality bears negative relation with all the three prime indicators - Q, RoCE, RoE, proving the notion that concentration of both the powers in one hand may hamper the firm's decision making \& performance. However, duality is positively related to MASR \& Rev Growth. Thus, our H3 stands fully accepted. 


\section{InsiderHold \& Firm Performance:}

As against our expectation, Insider Holding has a negative relation with Q. But it carries positive relation with RoCE, RoE, MASR \& Revenue Growth, thereby proving that greater corporate insider control may help in promoting shareholders' interests. Simultaneously, the non-monotonous aspect of Insider holding is being displayed across all prime indicators as SqInsiderHold reverses its sign.

Thus, our H4 stands partially rejected.

\section{InsttBlockHold \& Firm Performance:}

Institutional Block shareholding carries positive relation with Q, Revenue Growth \& MASR (as expected) but carries opposite relation with RoCE \& RoE. Thus, our H5 stands partially accepted.

\section{NonInsttBlockHold \& Firm Performance:}

NonInsttBlockHold carries positive relation with most indicators except RoCE\& Revenue Growth.

Thus our H6 stands partially accepted.

\section{Regression Estimates with Cost of Capital}

The relationship between corporate governance factors and the cost of capital is then estimated and we employ the set of control variables described earlier. TABLE-3 reports the estimation results for the cost of capital measure regressed on combinations of the governance variables.

\begin{tabular}{|c|c|c|c|c|}
\hline Dependent Variables $\rightarrow$ & Expected Sign & $\begin{array}{l}\text { WaCC } \\
\text { Unstandardized } \\
\text { Coefficients (B) }\end{array}$ & $\begin{array}{l}\mathrm{Ke} \\
\text { Unstandardized } \\
\text { Coefficients (B) }\end{array}$ & $\begin{array}{l}\text { Kd } \\
\text { Unstandardized } \\
\text { Coefficients (B) }\end{array}$ \\
\hline (Constant) & $?$ & 42.837 & 41.335 & -11.180 \\
\hline Board Independence (\%) & - & 31.682 & 44.280 & -3.107 \\
\hline Log of Board Size & + & -17.439 & -25.112 & 3.279 \\
\hline CEO or MD Duality & + & -2.561 & -2.372 & 13.913 \\
\hline $\begin{array}{l}\text { \%age Shareholding by Promoters \& Insiders } \\
(\%)\end{array}$ & - & -.570 & -.864 & .333 \\
\hline Square of InsiderHolding (\%) & + & .330 & .695 & -.536 \\
\hline $\begin{array}{l}\text { More than } 5 \% \text { Shareholding by Financial } \\
\text { Instt }(\%)\end{array}$ & - & -.403 & -.219 & -.208 \\
\hline $\begin{array}{l}\text { More than } 5 \% \text { Shareholding by Other Ext. } \\
\text { Instt }(\%)\end{array}$ & + & -.179 & -.183 & -.108 \\
\hline Log of Sales & - & -4.734 & -6.074 & 1.015 \\
\hline Debt/Equity & - & 2.661 & 3.511 & 2.108 \\
\hline 1 Year Beta & + & 24.622 & 30.811 & -15.619 \\
\hline LogAge & - & -11.600 & -16.548 & 24.631 \\
\hline No. of SBUs & + & -.893 & -1.812 & 1.917 \\
\hline Majorly Foreign owned & $?$ & 10.476 & 15.956 & -18.585 \\
\hline Majorly Indian Govt owned & $?$ & 5.083 & 6.389 & -5.712 \\
\hline Manufacturing \& Industry Sector & $?$ & 16.438 & 23.673 & -12.434 \\
\hline Service Sector excluding Financial Services & $?$ & 14.587 & 19.537 & -12.398 \\
\hline Financial Services Sector & $?$ & -15.034 & -24.688 & -.238 \\
\hline Credit Rating & - & 10.289 & 15.751 & -2.134 \\
\hline
\end{tabular}

The results show that corporate governance variables play a significant role in explaining the variations in a firm's cost of capital.

\section{Board Independence \& Cost of Capital:}

An increase in board independence (BoardInd) is associated with an increasein a firm's cost of capital, both $\mathrm{WaCC}$ and $\mathrm{K}_{\mathrm{e}}$. However, the result for $\mathrm{K}_{\mathrm{d}}$ is as anticipated, with cost of debt being negatively related to BoardInd, implying that greater number of independent directors on board serve as a measure of safety for debtlenders. This goes in consistence with the research that the appointment of the additional outside director reduces cost of debt (e.g., Anderson et al. 2004).

Thus, our H7 stands partially rejected.

\section{Board Size \& Cost of Capital:}

The larger number of directors on board seems to have a negative relation with the firm's cost of capital\& $\mathrm{K}_{\mathrm{e}}$. A larger BoardSizemay imply diversity of managerial talent \& experience with respect to decision 
making. This may result in relatively better performance by the firm, which may boost the investors' sentiments, entrusting them about the safety of their capital invested. However, for $\mathrm{K}_{\mathrm{d}}$, the result is positive correlation. Thus, our H8 stands partially accepted.

\section{CEO/MD Duality \& Cost of Capital:}

Existence of ExecDuality in a firm attracts lower cost of capital \& $\mathrm{K}_{\mathrm{e}}$. This goes against the idea that has been proposed by Yermack (1996) which finds that firms are more valuable when the CEO/MD and the chairman of the board are separate. Again, the result is opposite for $\mathrm{K}_{\mathrm{d}}$, implying that debt-lenders feel a greater level of risk in lending to a firm where one man controls chief executive as well as chairman post, thus they ask for greater return on debt.

Thus, our H9 stands partially accepted.

\section{Insider Holding \& Cost of Capital:}

Insider ownership (InsiderHold) has a significant negative relationship with cost of capital across all specifications of the model, suggesting that the higher is insider ownership; the lower is the cost of capital. The non-liner term (SqInsiderHold) also reverses its sign (although not significant), indicating the non-monotonic relation between insider ownership and the cost of capital. If insider ownership is too high, the risk of managerial entrenchment rises thereby increasing the cost of capital. The result is again opposite for $\mathrm{K}_{\mathrm{d}}$.

Thus our H10 stands partially accepted.

\section{Institution Block Shareholding \& Cost of Capital:}

Institutional block holdings (InsttBlockHold) are negatively related to the cost of capital, $\mathrm{K}_{\mathrm{e}}$ and $\mathrm{K}_{\mathrm{d}}$, suggesting that the higher institutional block holding, the lower is the cost of capital. The presence of financial institutions as block shareholders reduces the risks to minority shareholders as they ensure that cash flows are not diverted, and that capital is used optimally to maximize shareholder wealth. Thus, our H11 stands completely accepted.

\section{Non-Institution Block Shareholding \& Cost of Capital:}

The results for NonInsttBlockHold are the weakest of all the governance variables. This result is consistent with our expectation that some block holders may also pressurize the management to safe-guard them against risk associated with the capital that they have invested and thus their presence could act to decrease the cost of capital $\left(\mathrm{K}_{\mathrm{e}} \& \mathrm{~K}_{\mathrm{d}}\right.$ too).

Thus, our H12 stands completely accepted.

Regression Estimates with Control Variables

\section{Firm Size \& Cost of Capital:}

The size variable measured by [Log of Sales] is significant throughout all specifications. This indicates that large firms are likely to have a lower cost of capital. From a governance perspective, large firms may be more transparent and thus easier to monitor, leading investors to demand lower returns. The result is consistent even with Cost of Equity. However, for Cost of Debt, a positive relation prevails with FirmSize.

\section{Leverage \& Cost of Capital:}

The firm's leverage carries direct relation with its Cost of capital (WaCC, $\mathrm{K}_{\mathrm{e}}, \mathrm{K}_{\mathrm{d}}$ ). It implies that higher the financial risk inducted by the firm, higher shall be its cost of capital. The beta coefficient for Leverage is not very high, which aligns the result with the theory that higher debt component (after a certain level) may induce safety concerns within equity investors as well as lenders, thus urging them to demand a greater return for their investments.

\section{Risk \& Cost of Capital:}

The systematic risk related to a firm, as measured by one year beta, is positively related with firm's cost of capital and cost of equity. This may be consistent with the notion that equity investors are not willing to park their savings/funds in an industry or economy which bears high risk and so as to get equity investments in such industries, the corporates need to offer heavy returns, atleast in form of dividends. The result is however not consistent in case of Cost of debt which is negatively correlated with overall risk.

\section{Age of Firm \& Cost of Capital:}

The firm's age (LogAge) is negatively related to Cost of capital \& Cost of equity, implying that as firm spends more time (years) in the industry/economy, it gains experience \& better efficiency in its operations. A 
learning curve starts building up for the firm and the firm is able to lower its cost of capital. The cost of debt is however positively related to firm's age.

\section{Diversification\& Cost of Capital:}

As firm diversifies its operations \& has more SBUs, it tends to grow in its size. The results for firm's size relation with cost of capital have already been established earlier. The same holds true in case of Diversification as well.

\section{Credit Rating \& Cost of Capital:}

The results are as anticipated. For the firms that avail higher credit ratings like AAA and AA for their long term debt instruments (prior to the issue), they are able to enjoy lower cost of debt; since higher credit rating ensures low probability of interest \& principal default by the issuer. The credit ratings unfortunately bear positive relation with $\mathrm{WaCC}$ and $\mathrm{K}_{\mathrm{e}}$ for this dataset.

\section{Value Creation}

Finally we reach to last analysis in our present study, which is to see, if the corporate governance variables can actually create Value for the firm and for the shareholder's wealth. Value is created when a company is able to get a return on its investments (RoCE) higher than its cost of the capital invested (WaCC). Cost of capital is nothing but the minimum rate of return required by the investors.

Thus, Value can be created through 'Spread', if Spread is positive.

$$
\text { i.e. } \text { Value }=\text { Spread }=(\operatorname{RoCE}-\mathrm{WaCC}) ; \text { and Spread }>0
$$

To analyze the impact of governance variables over Spread, we try to regress the governance variables (explanatory variables) with Spread (explained variable) in the presence of Control variables, Performance variables \& Cost of capital variables.

Regression Estimates with Spread is presented in the TABLE-4 :

\begin{tabular}{|c|c|c|c|c|c|c|}
\hline \multicolumn{7}{|c|}{ Table-4 : Coefficientsa: Regression Estimates : CG Indicators with Spread } \\
\hline \multirow{2}{*}{\multicolumn{2}{|c|}{ Model }} & \multicolumn{2}{|c|}{ Unstandardized Coefficients } & \multirow{2}{*}{$\begin{array}{l}\text { Standardized } \\
\text { Coefficients } \\
\text { Beta }\end{array}$} & \multirow[t]{2}{*}{$\mathrm{t}$} & \multirow[t]{2}{*}{ Sig. } \\
\hline & & B & Std. Error & & & \\
\hline \multirow[t]{17}{*}{1} & (Constant) & 3.040 & 21.790 & & .140 & .889 \\
\hline & Board Independence (\%) & 5.807 & 12.944 & .020 & .449 & .654 \\
\hline & Log of Board Size & 6.192 & 14.716 & .022 & .421 & .674 \\
\hline & CEO or MD Duality & -21.966 & 3.331 & -.317 & -6.595 & .000 \\
\hline & $\begin{array}{l}\text { \%age Shareholding by Promoters \& } \\
\text { Insiders (\%) }\end{array}$ & .598 & .235 & .466 & 2.547 & .012 \\
\hline & Square of InsiderHolding (\%) & -.394 & .213 & -.263 & -1.852 & .065 \\
\hline & $\begin{array}{l}\text { More than } 5 \% \text { Shareholding by } \\
\text { Financial Instt (\%) }\end{array}$ & -.218 & .179 & -.112 & -1.217 & .225 \\
\hline & $\begin{array}{l}\text { More than } 5 \% \text { Shareholding by Other } \\
\text { Ext. Instt }(\%)\end{array}$ & -.274 & .104 & -.112 & -2.621 & .009 \\
\hline & Log of Sales & 3.513 & 2.710 & .062 & 1.296 & .196 \\
\hline & Debt/Equity & -1.880 & .544 & -.168 & -3.456 & .001 \\
\hline & 1 Year Beta & -13.120 & 4.600 & -.123 & -2.853 & .005 \\
\hline & LogAge & -.553 & 5.930 & -.005 & -.093 & .926 \\
\hline & No. of SBUs & 4.807 & .898 & .352 & 5.353 & .000 \\
\hline & Cost of Equity (\%) & -.770 & .037 & -.753 & -21.053 & .000 \\
\hline & Cost of Debt (\%) & .031 & .044 & .027 & .715 & .476 \\
\hline & Credit Rating & 2.140 & 6.411 & .018 & .334 & .739 \\
\hline & Revenue Growth Rate (\%) & .184 & .078 & .088 & 2.355 & .019 \\
\hline \multicolumn{3}{|c|}{ a. Dependent Variable: Spread (RoCE - WaCC) (\%) } & & & & \\
\hline
\end{tabular}

Board Independence and Spread: Spread, which is the value additive indicator of a firm, is positively correlated with the independence level of the board, implying that greater the number of independent nonexecutive directors on $\mathrm{BoD}$, higher will be the value added to the firm \& to the shareholders. 
Board Size and Spread: However, the spread is positively aligned with board size too, which reflects that a more the number of directors on board, the better value shall be added to the firm $\&$ investors.

CEO/MD Duality and Spread: Executive duality is highly negatively related to Spread, which confirms the theory that concentration of $\mathrm{CEO} / \mathrm{MD}$ and Chairman's power in one hand leads to dampening value to the investors.

Insider Holding and Spread: Corporate Insider holdings are significantly and positively related to Spread, which justify the fact that when concentration of insiders holdings increase, then they align their activities \& decisions in the context of shareholders, thereby leading to decisions which add greater value to the shareholders' wealth. The SqInsiderHold variable changes its sign w.r.t. Spread, thereby proving the nonmonotonous function of corporate insider holdings. When Corporate insider holdings increase a lot, then they emerge out as block shareholders sometimes and their decisions, then, collude with the interests of minority shareholders.

Institutional Block Shareholding and Spread: The negative relation between the two suggests that as external financial institutions acquire more stake into the company, they tend to influence the performance $\&$ decision making of management (so that their own lent debt capital remains safe), which sometimes may hamper the overall returns \& value of the firm.

Non-Institutional Block Shareholding and Spread: The relation, results and inference is same as that in case of InsttBlockHold, perhaps for the similar reasons. Some block holders are also capable of colluding with management to expropriate other minorities and thus their presence could act to increase the cost of capital.

Control Variables and Spread: The value additive spread is positively related to the firm size, firm diversification, credit rating, cost of debt $\&$ revenue growth rate, implying that a larger and highly diversified firm is able to enjoy an experience curve which may substantially improve its performance and thus add value to shareholders' wealth. A better credit rating can also help the firm to raise funds from the market at lower cost \& also boost the investor sentiments. The spread is however negatively related to cost of equity \& leverage.

\section{Singhal's V - Score Model}

Capital \& value additive Spread reveals some significant, generalized as well as unexpected results. While the widely accepted notion that - value addition takes place when Board independence, Corporate Insider holding and firm size are positively related to governance variables \& when CEO duality and firm's financial risk are negatively aligned to governance variables - holds true in our study as well, the behaviour of board size, institutional block shareholding, non-institutional block holding \& credit rating with firm's value additive measures are quite unexpected.

Anyhow, going further with our study, we calculated the Spread (RoCE - WaCC) of each of the 22 companies for each of the 10 years of study. The maximum spread turns out to be $122.56 \%$ (HUL in FY 2008) and the minimum spread being $-74.09 \%$ (loss in value for Axis bank in FY 2009).

The mean spread fall near $9.67 \%$ which we set as our benchmark spread in this study. This implies that, for our current sample study, any spread (earned by any company in any FY) which is greater than our benchmark rate of $\mathbf{9 . 6 7 \%}$ shall be regarded as "High Spread (denoted by dummy 1)" - thereby capable of adding High Value to the firm. On the contrary, any spread earned less than $9.67 \%$ shall be taken as "Low value additive Spread (denoted by dummy 0 )".

Now that we have two categorical variables of High Spread creation \& Low Spread creation, we would like to devise a model that can predict \& estimate - "Whether a Firm will Add High Value (spread) for its Investors or Not", just by looking at certain firm related corporate governance factors along with other variables related to firm's performance and cost.

We accomplish this by employing Discriminant Analysis statistical tool in SPSS. 
SPSS reports that w.r.t. the grouping variables of Spread Creation ( $0=$ Low Spread, 1=High Spread), 95 readings are for Low Spread creation whereas 125 readings are for High Spread creation.

The Eigen Value is high implying that more variance in the dependent variable is explained by the discriminant function. A lower Wilk's Lambda displays the greater discriminating ability of independent variables towards both groups. Finally, a high Canonical Correlation measures the high degree of association between discriminant function \& dependent variables. See (Data-4) and (Data-5) in Appendix.

The discriminant scores created using canonical discriminant functions coefficients (unstandardized) are in the form of: [See (Data-8) in Appendix]

$$
\begin{gathered}
\mathrm{V}^{\prime}=0.785-2.101 \mathrm{~A}+0.67 \mathrm{~B}+0.373 \mathrm{C}-0.001 \mathrm{D}+0.009 \mathrm{E}+0.008 \mathrm{~F}-0.224 \mathrm{G}+0.188 \mathrm{H}+0.037 \mathrm{I}-0.007 \mathrm{~J} \\
-0.807 \mathrm{~K}-0.005 \mathrm{~L}-0.002 \mathrm{M}
\end{gathered}
$$

Without explaining the connotations of these explanatory variables, we will further try to reduce this equation into:

$$
\mathrm{V}=0.785-2.101 \mathrm{~A}+0.67 \mathrm{~B}+0.373 \mathrm{C}+0.009 \mathrm{E}-0.224 \mathrm{G}+0.188 \mathrm{H}+0.037 \mathrm{I}-0.807 \mathrm{~K}
$$

Where,

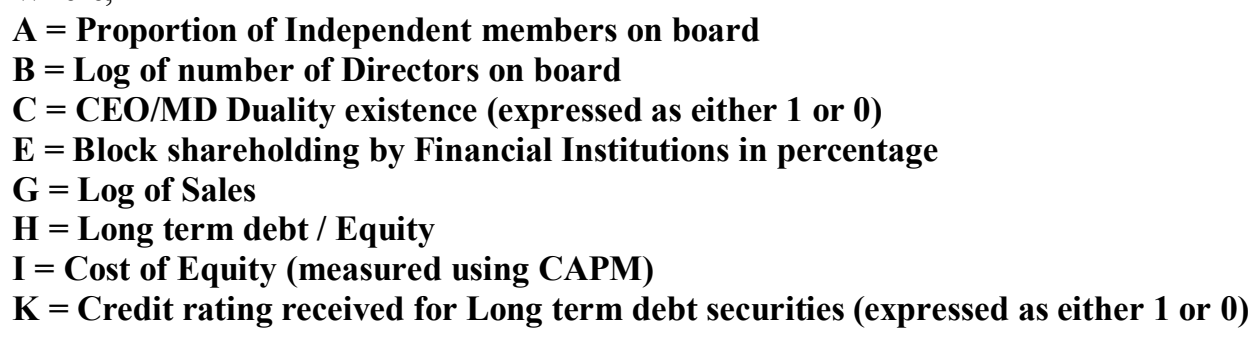

The Functions at Group Centroid reveals that the mean discriminant V-score for the firms that create Low Spread (Value) is 1.168 and the mean discriminant V-score for the firms that create High Spread is -0.888 . See (Data-9) in Appendix.

It means that, for a given sample of companies or a given company, if:

$\mathrm{V} \leq \mathbf{- 0 . 8 8 8}$, then, Very High Spread (Value) is created by firm for its investors. $-0.888<\mathrm{V}<1.168$, then, Moderate Value is created by firm for its investors. $V \geq 1.168$, then, Low/Negative Value is created by firm for its investors.

\section{Conclusions \& Recommendations}

The purpose, for which the present study was conducted, was to find an alternate measure to Firm Performance indicators like Tobin Q, which add Value to the firm and to the Shareholder's wealth and which is more stable (or carry less variance). We anticipated that Cost of Capital would have lesser standard deviation vis-à-vis firm performance indicators. But the study conducted on the sample of SENSEX companies ousted our anticipation, as it showed that Tobin Q, RoCE, RoE are much more stable \& consistent indicators to Firm's Value than the cost of capital.

Tobin Q, which is widely accepted proxy to Firm's value, is positively related to Board Independence and is inversely related to Board Size and CEO/MD Duality, thereby justifying most of the prior theories \& research on role of board composition in reducing Agency cost.

Tobin Q's non-monotonous relation with corporate Insider shareholding was also near to our expectation. In terms of other measures of ownership, Q is positively related to Institutional block shareholders and Non-institutional block shareholders, implying their role in maintaining outside control \& vigilance over management's activities. 
In terms of Cost of Capital (especially WaCC), the Board Independence bears positive relation and Board Size along with CEO/MD Duality carry inverse relation with the Cost of Capital - all the three results as opposed to our prior expectation. In terms of ownership pattern, the Insider Holding as well as Institutional Block shareholding gets aligned with our anticipations as both are negatively related to Cost of Capital.

Cost of Debt appears to bear opposite results than WaCC and Cost of Equity, in most cases. However, $\mathrm{K}_{\mathrm{d}}$ is inversely aligned to Board independence, institutional block shareholding, credit rating, and positively correlated to Board size, CEO/MD duality and Leverage - all these being as per our expectation.

The Value additive indicator 'Spread' carries positive \& significant relation with Board independence, Insider holding, firm size \& credit ratings, but is inversely related to CEO duality; and all this goes in tandem with the previous studies w.r.t. Value addition to the shareholders' wealth.

Looking at all the measures aggregately, our present research has indicated a positive relation of Board Size, Board independence, Insider holding, NonInstthold, firm size, diversification \& age with most Value indicators. On the other hand, most value indicators bear negative relation with CEO Duality, InsttBlockHold, Leverage, risk \& credit rating.

Therefore, based on the current research, we recommend a moderate board size with high degree of independence but no CEO/MD duality, larger \& diversified firm's operations, and greater stake of corporate insiders but low level of financial risk (leverage).

Finally we have our Singhal's V-score value predictive model, as per which, the firms with V-score less than -0.888 are expected to earn a higher spread or returns over their minimum required rate, whereas the firms with V-score more than 1.168 are likely to earn a rate of return (on their investments) lesser than the minimum required rate, thereby diminishing the investor's value.

Apart from all this, our results say that SENSEX companies, on an average, have a moderate board size of $12-13$, board independence greater than $50 \%$, annual revenue growth of $19 \%, 29 \%$ Return on Investments and $19 \%$ cost of capital. This gives the SENSEX companies a Value additive spread of around $10 \%$.

Given the above stated results, we recommend (for the sample as alike ours) that Tobin Q should be preferred as a measure to judge corporate Value formation vis-à-vis Cost of Capital. We also recommend a moderate board size of about 10 members with board independence not less than $50 \%$. Also, we recommend the separation of CEO/MD and Chairman in an organisation, along with proposed greater shareholding by corporate insiders and institutional block shareholders.

Our findings \& recommendations have implications for policy makers, regulators, managers, investors and researchers in the emerging markets. Our comprehensive evidence on the impact of corporate governance on firm performance should help the policy makers and regulators of the emerging markets make relevant policies and assess the effectiveness of these policies. Thus they could set a competitive legal and regulatory infrastructure to effectively and efficiently attract foreign capital. They should also continue to promote corporate governance among the listed firms. In addition, our findings have implications for the managers of public companies with regards to the importance of corporate governance as they strive to improve firm performance and valuation. Thus managers and board of directors of listed firms should adopt high standard of corporate governance. As to the investors, it is important to learn how corporate governance indicates companyspecific risk so that they could make better investment decisions. Since this study suggests better governed firms perform better, paying attention to some of the corporate governance metrics and avoiding investment in firms with poor governance could help investors to improve the performance of their portfolio.

\section{Limitation}

There are variety of mechanisms and market forces which reduce agency cost and complement or substitute board independence. Also, the exact shareholding by CEO or chairman in the company is not easily available. Despite providing for controls in the analysis, the impact of governance mechanism is difficult to segregate.

The data has been collected from Capitaline database. Mistakes were detected in the data and were corrected. While care was taken to ensure all corrections are made, some of them might have been inadvertently overlooked. The classification of sectors into different categories was as mentioned in the corporate governance 
reports which are a part of annual reports. It was assumed that the companies are reporting fairly to the regulators and stock exchanges and misrepresentation would entice legal actions.

Studies on board composition were not conducted before 2005; the deadline year by which all listed companies had to comply with the Listing Agreements as per SEBI Clause-49. Longer time horizon for the study should have been selected.

\section{Assumptions}

- Book value of debt is used as a proxy to the Market value of debt in calculating Tobin Q.

- Log of Sales, Log of Board Size and Log of Age has been taken for data normality purpose.

- The Sales figures used in the project are the Net Sales of the companies.

- $\mathrm{Rm}$ is the one yearly arithmetic return on SENSEX.

- $\mathrm{Ri}$ is the one yearly arithmetic return on Average Share Prices of a company.

- It is assumed that all the 22 companies of SENSEX used in the analysis, strictly adhere to SEBI's Listing Agreement under Clause-49.

- In case of banking companies, Borrowings has been used as a proxy to Total Debt.

- In case of banking companies, Interest Expended is used as a proxy to Interest Liability on loans.

- In case of banking companies, Total Debt to Owner's Fund is used as a proxy to Long term debt/Equity.

- In case of banking companies, Total Income/Capital Employed is used as a proxy to RoCE.

- Credit Ratings for long term debt instruments have been classified as HIGH if they signify Highest/High Safety level (AAA, AA or LAAA, LAA etc.). In rest of the cases, the rating shall be taken as LOW/MODERATE.

- For Credit ratings, long term debt securities like Debt Progamme, Long term Debentures, Non-convertible debentures, Bonds, Term loan Programme etc. are taken.

- $\mathrm{MD}$ is taken as a proxy to $\mathrm{CEO}$ in companies where there is no existing CEO.

\section{Scope \& Guidelines For Future Research}

The qualifications of the directors, their age, and whether they affect the board composition is moderated by these factors, need to be looked into.

Different companies can have different board size \& compositions that are appropriate. Further studies can be taken up to see which board composition is suitable for different companies which are in different stages of their life cycle. Boardroom behaviour is also important. Future researchers can observe and study boardroom behaviour by actually attending the board meetings.

Besides composition, other factors like number of meetings, the time for which they last, the attendance record of independent directors, the number of agenda items in the board meetings etc., are also important and can be included in the future study. 


\section{References}

[1]. Agrawal, A. and C.R. Knoeber, 1996, "Firm Performance and Mechanisms to Control Agency Problems Between Managers and Shareholders", Journal of Financial and Quantitative Analysis 31, 377.397.

[2]. Bhagat, S. and B. Black, 2002, "Board Independence and Long-Term Performance", Journal of Corporation Law 27, 231-273.

[3]. Fama, E. and M. Jensen. 1983. Separation of ownership and control. Journal of Law and Economics (June): 301-325.

[4]. Gompers, P. Ishii, J. And A. Metrick, 2003, "Corporate Governance and Equity Prices", Quarterly Journal of Economics 118, 107 155.

[5]. Goyal, V.K. \& Park, C.W. (2002): "Board Leadership Structure and CEO Turnover”, Journal of Corporate Finance, vol 8, No. 1, pp 49-66.

[6]. Lipton, M. and Lorsch, J.W. (1992): “A Modest Proposal for Improved Corporate

[7]. Sami, H. and Wang, J.T. (2009): "Corporate Governance and Operating Performance of Chinese Listed Firms"

[8]. Yermack, D., 1996. "Higher Valuation of Companies with a Small Board Of Directors", Journal of Financial Economics 40, 185 212.

\section{Appendix}

\begin{tabular}{|c|c|c|c|c|c|}
\hline & \multicolumn{5}{|c|}{ Descriptive Statistics (Data-1) } \\
\hline & \multirow{2}{*}{\begin{tabular}{|l}
$\mathrm{N}$ \\
Statistic \\
\end{tabular}} & \multicolumn{2}{|c|}{ Skewness } & \multicolumn{2}{|l|}{ Kurtosis } \\
\hline & & Statistic & Std. Error & Statistic & Std. Error \\
\hline $\begin{array}{l}\text { Prop of Independent members on } \\
\mathrm{B} \circ \mathrm{D}(\%)\end{array}$ & 220 & -.339 & .164 & 1.094 & .327 \\
\hline No. of Directors on Board & 220 & -.078 & .164 & -.061 & .327 \\
\hline $\begin{array}{l}\text { \%age Shareholding by Promoters } \& \\
\text { Insiders }(\%)\end{array}$ & 220 & -.201 & .164 & -1.010 & .327 \\
\hline $\begin{array}{l}\text { More than } 5 \% \text { Shareholding by } \\
\text { Financial Instt }(\%)\end{array}$ & 220 & .522 & .164 & .071 & .327 \\
\hline $\begin{array}{l}\text { More than } 5 \% \text { Shareholding by } \\
\text { Other Ext. Instt }(\%)\end{array}$ & 220 & 1.765 & .164 & 2.078 & .327 \\
\hline Cost of Equity $(\%)$ & 220 & -.254 & .164 & .642 & .327 \\
\hline Cost of Debt $(\%)$ & 220 & 9.027 & .164 & 101.067 & .327 \\
\hline Overall Cost of Capital $(\%)$ & 220 & -.361 & .164 & .223 & .327 \\
\hline Tobin Q & 220 & 9.770 & .164 & 120.843 & .327 \\
\hline Market Adjusted Stock Return (\%) & 220 & .165 & .164 & .812 & .327 \\
\hline Return on Capital Employed (\%) & 220 & 1.734 & .164 & 3.787 & .327 \\
\hline Return on Equity $(\%)$ & 220 & 2.120 & .164 & 5.936 & .327 \\
\hline 1 Year Beta & 220 & .267 & .164 & -.493 & .327 \\
\hline Debt/Equity & 220 & 3.118 & .164 & 10.087 & .327 \\
\hline Revenue or Sales Growth Rate $(\%)$ & 220 & .282 & .164 & 2.450 & .327 \\
\hline $\mathrm{RoCE}-\mathrm{WaCC}(\%)$ & 220 & .604 & .164 & .517 & .327 \\
\hline Valid N (listwise) & 220 & & & & \\
\hline
\end{tabular}

Model Summary of Regression with Spread (Data-2)

\begin{tabular}{|l|l|l|l|l|}
\hline Model & R & R Square & Adjusted R Square & $\begin{array}{l}\text { Std. Error of the } \\
\text { Estimate }\end{array}$ \\
\hline 1 & $.871 \mathrm{a}$ & .759 & .740 & 17.68232880 \\
\hline
\end{tabular}

ANOVAb table for Regression with Spread (Data-3)

\begin{tabular}{|ll|l|l|l|l|l|}
\hline Model & & Sum of Squares & Df & Mean Square & F & Sig. \\
\hline 1 & Regression & 200374.690 & 16 & 12523.418 & 40.054 & $.000 \mathrm{a}$ \\
& Residual & 63470.945 & 203 & 312.665 & & \\
& Total & 263845.635 & 219 & & & \\
\hline
\end{tabular}

Summary of Canonical Discriminant Functions Eigenvalues (Data-4)

\begin{tabular}{|l|l|l|l|l|}
\hline Function & Eigenvalue & $\%$ of Variance & Cumulative \% & Canonical Correlation \\
\hline 1 & $1.046 \mathrm{a}$ & 100.0 & 100.0 & .715 \\
\hline
\end{tabular}

a. First 1 canonical discriminant functions were used in the analysis. 
Wilks' Lambda (Data-5)

\begin{tabular}{|l|l|l|l|l|}
\hline Test of Function(s) & Wilks' Lambda & Chi-square & df & Sig. \\
\hline 1 & .489 & 151.417 & 13 & .000 \\
\hline
\end{tabular}

Tests of Equality of Group Means for Discriminant Analysis (Data-6)

\begin{tabular}{|c|c|c|c|c|c|}
\hline & Wilks' Lambda & F & df1 & $\mathrm{df} 2$ & Sig. \\
\hline Prop of Independent members on $\mathrm{BoD}(\%)$ & 1.000 & .007 & 1 & 218 & .931 \\
\hline Log of Board Size (No. of Directors) & .999 & .173 & 1 & 218 & .678 \\
\hline CEO or MD Duality & .999 & .165 & 1 & 218 & .685 \\
\hline $\begin{array}{l}\text { \%age Shareholding by Promoters \& Insiders } \\
(\%)\end{array}$ & .987 & 2.805 & 1 & 218 & .095 \\
\hline $\begin{array}{l}\text { More than } 5 \% \text { Shareholding by Financial } \\
\text { Instt (\%) }\end{array}$ & .991 & 1.934 & 1 & 218 & .166 \\
\hline $\begin{array}{l}\text { More than } 5 \% \text { Shareholding by Other Ext. } \\
\text { Instt (\%) }\end{array}$ & 1.000 & .042 & 1 & 218 & .838 \\
\hline Log of Sales & .987 & 2.983 & 1 & 218 & .086 \\
\hline Debt/Equity & .911 & 21.399 & 1 & 218 & .000 \\
\hline Cost of Equity (\%) & .599 & 145.967 & 1 & 218 & .000 \\
\hline Cost of Debt (\%) & .998 & .525 & 1 & 218 & .469 \\
\hline $\begin{array}{l}\text { Credit Rating recieved for Long Term Debt } \\
\text { Securities }\end{array}$ & .996 & .796 & 1 & 218 & .373 \\
\hline Revenue Growth Rate (\%) & .992 & 1.728 & 1 & 218 & .190 \\
\hline Tobin Q & .999 & .263 & 1 & 218 & .609 \\
\hline
\end{tabular}

Group Statistics for Discriminant Analysis (Data-7)

\begin{tabular}{|c|c|c|c|c|c|}
\hline \multirow{2}{*}{\multicolumn{2}{|c|}{ Spread $>$ Avg.Spread }} & \multirow[b]{2}{*}{ Mean } & \multirow[b]{2}{*}{ Std. Deviation } & \multicolumn{2}{|c|}{ Valid N (listwise) } \\
\hline & & & & Unweighted & Weighted \\
\hline \multirow[t]{13}{*}{$\begin{array}{l}\text { Low Value (Spread) created } \mathrm{P} \\
\text { for Firm }\end{array}$} & $\begin{array}{l}\text { Prop of Independent members on BoD } \\
(\%)\end{array}$ & .537561046 & .1265968108 & 95 & 95.000 \\
\hline & Log of Board Size (No. of Directors) & $1.093808781 \mathrm{E} 0$ & .1243087695 & 95 & 95.000 \\
\hline & CEO or MD Duality & .515789474 & .5024018459 & 95 & 95.000 \\
\hline & $\begin{array}{l}\text { \%age Shareholding by Promoters \& } \\
\text { Insiders (\%) }\end{array}$ & 3.987863158E1 & $2.8070637025 \mathrm{E} 1$ & 95 & 95.000 \\
\hline & $\begin{array}{l}\text { More than } 5 \% \text { Shareholding by Financial } \\
\text { Instt (\%) }\end{array}$ & 3.306189474E1 & $1.9504904691 \mathrm{E} 1$ & 95 & 95.000 \\
\hline & $\begin{array}{l}\text { More than } 5 \% \text { Shareholding by Other Ext. } \\
\text { Instt (\%) }\end{array}$ & $8.963684211 \mathrm{E} 0$ & 1.4278049367E1 & 95 & 95.000 \\
\hline & Log of Sales & $4.076476367 \mathrm{E} 0$ & .7755376619 & 95 & 95.000 \\
\hline & Debt/Equity & $2.372210526 \mathrm{E} 0$ & 4.1358827247E0 & 95 & 95.000 \\
\hline & Cost of Equity (\%) & $4.456759641 \mathrm{E} 1$ & $2.3280064643 \mathrm{E} 1$ & 95 & 95.000 \\
\hline & Cost of Debt (\%) & 8.622976279E0 & $1.5183510000 \mathrm{E} 1$ & 95 & 95.000 \\
\hline & $\begin{array}{l}\text { Credit Rating recieved for Long Term } \\
\text { Debt Securities }\end{array}$ & .884210526 & .3216697757 & 95 & 95.000 \\
\hline & Revenue Growth Rate (\%) & 2.081947368E1 & 1.7683615170E1 & 95 & 95.000 \\
\hline & Tobin Q & $5.690092121 \mathrm{E} 0$ & $1.5733933016 \mathrm{E} 1$ & 95 & 95.000 \\
\hline \multirow{8}{*}{$\begin{array}{l}\text { High Value (Spread) created I } \\
\text { for Firm }\end{array}$} & $\begin{array}{l}\text { Prop of Independent members on BoD } \\
(\%)\end{array}$ & .536141608 & .1167902198 & 125 & 125.000 \\
\hline & Log of Board Size (No. of Directors) & $1.086955391 \mathrm{E} 0$ & .1186657831 & 125 & 125.000 \\
\hline & CEO or MD Duality & .488000000 & .5018674803 & 125 & 125.000 \\
\hline & $\begin{array}{l}\text { \%age Shareholding by Promoters \& } \\
\text { Insiders }(\%)\end{array}$ & $4.602728000 \mathrm{E} 1$ & $2.6110104408 \mathrm{E} 1$ & 125 & 125.000 \\
\hline & $\begin{array}{l}\text { More than } 5 \% \text { Shareholding by Financial } \\
\text { Instt (\%) }\end{array}$ & $2.970432000 \mathrm{E} 1$ & $1.6273004726 \mathrm{E} 1$ & 125 & 125.000 \\
\hline & $\begin{array}{l}\text { More than } 5 \% \text { Shareholding by Other Ext. } \\
\text { Instt (\%) }\end{array}$ & $8.564320000 \mathrm{E} 0$ & 1.4307181218E1 & 125 & 125.000 \\
\hline & Log of Sales & $4.218900182 \mathrm{E} 0$ & .4352542786 & 125 & 125.000 \\
\hline & Debt/Equity & .508560000 & $1.5605115497 \mathrm{E} 0$ & 125 & 125.000 \\
\hline
\end{tabular}




\begin{tabular}{|c|c|c|c|c|c|}
\hline & Cost of Equity (\%) & $1.279435247 \mathrm{E} 0$ & |2.8414610863E1 & 125 & 125.000 \\
\hline & Cost of Debt (\%) & $1.154312066 \mathrm{E} 1$ & 3.6967545101E1 & 125 & 125.000 \\
\hline & $\begin{array}{l}\text { Credit Rating recieved for Long Term } \\
\text { Debt Securities }\end{array}$ & 920000000 & .2723849269 & 125 & 125.000 \\
\hline & Revenue Growth Rate (\%) & $1.785720000 \mathrm{E} 1$ & $1.5647490142 \mathrm{E} 1$ & 125 & 125.000 \\
\hline & Tobin Q & $6.494787624 \mathrm{E} 0$ & $6.8102710227 \mathrm{E} 0$ & 125 & 125.000 \\
\hline \multirow[t]{13}{*}{ Total } & $\begin{array}{l}\text { Prop of Independent members on BoD } \\
(\%)\end{array}$ & .536754547 & .1208413800 & 220 & 220.000 \\
\hline & Log of Board Size (No. of Directors) & $1.089914809 \mathrm{E} 0$ & .1209022529 & 220 & 220.000 \\
\hline & CEO or MD Duality & .500000000 & .5011402523 & 220 & 220.000 \\
\hline & $\begin{array}{l}\text { \%age Shareholding by Promoters \& } \\
\text { Insiders (\%) }\end{array}$ & $4.337218182 \mathrm{E} 1$ & $2.7083872516 \mathrm{E} 1$ & 220 & 220.000 \\
\hline & $\begin{array}{l}\text { More than } 5 \% \text { Shareholding by Financial } \\
\text { Instt (\%) }\end{array}$ & $3.115418182 \mathrm{E} 1$ & $1.7776711197 \mathrm{E} 1$ & 220 & 220.000 \\
\hline & $\begin{array}{l}\text { More than } 5 \% \text { Shareholding by Other Ext. } \\
\text { Instt (\%) }\end{array}$ & $8.736772727 \mathrm{E} 0$ & $1.4263331665 \mathrm{E} 1$ & 220 & 220.000 \\
\hline & Log of Sales & 4.157398989E0 & .6086265638 & 220 & 220.000 \\
\hline & Debt/Equity & $1.313318182 \mathrm{E} 0$ & $3.0946686205 \mathrm{E} 0$ & 220 & 220.000 \\
\hline & Cost of Equity (\%) & 1.997205029E1 & 3.3935667234E1 & 220 & 220.000 \\
\hline & Cost of Debt (\%) & $1.028214922 \mathrm{E} 1$ & $2.9577640692 \mathrm{E} 1$ & 220 & 220.000 \\
\hline & $\begin{array}{l}\text { Credit Rating recieved for Long Term } \\
\text { Debt Securities }\end{array}$ & .904545455 & .2945118595 & 220 & 220.000 \\
\hline & Revenue Growth Rate (\%) & $1.913636364 \mathrm{E} 1$ & $1.6583683830 \mathrm{E} 1$ & 220 & 220.000 \\
\hline & Tobin Q & $6.147305475 \mathrm{E} 0$ & $1.1518571708 \mathrm{E} 1$ & 220 & 220.000 \\
\hline
\end{tabular}

Canonical Discriminant Function Coefficients (Data-8)

\begin{tabular}{|l|l|}
\hline & Function \\
\cline { 2 - 2 } & 1 \\
\hline Prop of Independent members on BoD (\%) & -2.101 \\
Log of Board Size (No. of Directors) & .670 \\
CEO or MD Duality & .373 \\
\%age Shareholding by Promoters \& Insiders & \\
\%) & -.001 \\
More than 5\% Shareholding by Financial & .009 \\
Instt (\%) & \\
More than 5\% Shareholding by Other Ext. & .008 \\
Instt (\%) & -.224 \\
Log of Sales & .188 \\
Debt/Equity & .037 \\
Cost of Equity (\%) & -.007 \\
Cost of Debt (\%) \\
Credit Rating recieved for Long Term Debt \\
Securities \\
Revenue Growth Rate (\%) \\
Tobin Q \\
(Constant)
\end{tabular}

Unstandardized coefficients

Functions at Group Centroids (Data-9)

\begin{tabular}{|l|l|}
\hline \multirow{2}{*}{ Spread $>$ Avg.Spread } & Function \\
\cline { 2 - 2 } & 1 \\
\hline Low Value (Spread) created for Firm & 1.168 \\
High Value (Spread) created for Firm & -.888 \\
\hline
\end{tabular}

Unstandardized canonical discriminant functions evaluated at group means 